Brit. J. industr. Med., 1959, 16, 221.

\title{
SOME HAZARDS IN THE MANUFACTURE AND USE OF PLASTICS
}

\author{
BY \\ D. KENWIN HARRIS \\ From Imperial Chemical Industries Ltd. (Plastics Division)
}

(RECEIVED FOR PUBLICATION JANUARY 13, 1959)

The expansion of the plastics industry during the last few years has introduced the possibility of hazards from new polymers and from modifications to old products. The first two sections of this paper deal with the diminishing incidence of dermatitis in synthetic resin plants using formaldehyde and with the toxic properties of some chemicals added during the manufacture of polyvinyl chloride compositions. After a brief reference to the hazards of catalysts used in the manufacture of new polymers in the polythene series, an account is given of the dangers of polytetrafluoroethylene. At high temperatures this important new polymer gives rise to decomposition products that may be harmful when inhaled, and smoking contaminated tobacco is one of the commonest ways in practice by which workmen may be affected. Animal experiments have confirmed the dangers of excessive heating of this polymer although the symptoms differ from those in human beings so that it is still not possible to incriminate any one of the products evolved at these temperatures. In a description of the hazards of manufacture of copolymers of butadiene that are new to this country the toxic properties of the monomers are given in some detail since some of these could prove harmful to the factory worker unless adequate precautions are taken, although the final materials are inert and free from danger.

There is an increasing demand for the use of plastics by the general public and in specialized fields. They are widely used in the food industry and for domestic articles so that it is important that both the raw materials and the final article will not contaminate food or beverages. None of the constituents of the plastics should be capable of being extracted by the food or drink with which they come into contact, but in order to ensure this it is more convenient in practice to submit them in the first place to the action of a few selected solvents. Depending on the results of these initial experiments the materials may subsequently have to be submitted to pharmacological tests which may take several weeks to be completed. Three unusual problems in this field are described.

The most difficult application in which to ensure freedom from danger is probably in the surgical use of plastics. Surgeons already have wide experience of the technique of handling and using plastics. Although the effects of a few selected plastics have been investigated and described, the response of living tissues to these materials is often unpredictable. The results of implantation in many patients will not be available for several years and it is suggested that the misuse of plastics in this field presents dangers that may not always be appreciated.

The growth of the plastics industry over the last few years has been such that there are few people nowadays who are unfamiliar with at least some of its products. Their application for domestic purposes alone has made them well known to the public, but this represents only a small section of the field in which plastics are proving useful and often essential materials. It is this continually increasing diversity of uses, together with the ability of the chemist to synthesize new polymers or macro- molecules, that chiefly suggests the extraordinary OUTPUT OF PLASTICS

\begin{tabular}{l|r|r|r|r|r|r|r|r}
\hline \multirow{2}{*}{ Country } & \multicolumn{8}{|c}{ Thousands of Tons } \\
\cline { 2 - 9 } & 1950 & 1951 & 1952 & 1953 & 1954 & 1955 & 1956 & 1957 \\
\hline Great & & & & & & & & \\
$\quad$ Britain & 155 & 195 & 180 & 210 & 274 & 316 & 338 & 393 \\
France & 33 & 40 & 35 & 53 & 85 & 100 & 127 & 160 \\
Germany & 98 & 168 & 190 & 241 & 326 & 400 & 480 & 580 \\
Italy & 23 & 26 & 29 & 52 & 77 & 122 & 141 & 125 \\
Japan & 18 & 42 & 50 & 65 & 87 & 128 & 200 & 278 \\
U.S.A. & 825 & 895 & 882 & 1,045 & 1,134 & 1,442 & 1,544 & 1,800 \\
\hline
\end{tabular}


possibilities of future expansion in the industry. The striking post-war development may perhaps be most clearly demonstrated by the foregoing table showing the quantities of plastic raw materials produced in various countries.

In view of this rapid growth it should hardly be necessary to emphasize the need for ensuring the health and safety, not only of those engaged in the manufacture of the products, but of the millions of people who use them. Protection of the workmen in the factory is ensured without much difficulty by adopting principles of occupational hygiene, but the use, for example, of the final plastic material for food containers or in surgery needs careful consideration and frequently a detailed investigation of the product and its ingredients. A typical example is in the stringent regulations applied to packing materials by the Food and Drugs Administration of the United States (Lehman, 1956).

The basis of every plastic material is the polymer and this is synthesized today from chemicals made from such basic products as air, water, salt, lime, coal, petroleum, fluorspar, and agricultural products. The pathological effects which may result from the more common plastics and their constituents have been described by Mallette and Haam (1952a and b), Wilson and McCormick (1955), Parmeggiani and Sassi (1955), Hine, Kodama, Anderson, Simonson, and Wellington (1958), and Oettel (1957).

It is proposed in this paper to deal mainly with hazards associated with plastics manufactured by a chemical organization which is the largest single manufacturer of plastics raw materials produced in the British Commonwealth. The paper includes comparatively recent developments in plastics and their applications, and it can be regarded as a supplement to a previous publication (Harris, 1953) which originally described one or two of the compounds to which further reference will now be made.

\section{Individual Plastics}

Formaldehyde Products.-Formaldehyde is used in very large quantities in the plastics industry, principally in the manufacture of urea formaldehyde and phenol formaldehyde resins and moulding powders. It is known to be an acute poison and skin irritant (Schwartz, Tulipan, and Peck, 1947). Its effects on the skin and by absorption have already been described (Harris, 1953) so that only a brief reference to the subject is necessary here. In synthetic resin plants using formaldehyde the incidence of dermatitis has gradually been reduced to negligible proportions in recent years although production has increased by roughly $50 \%$; the number of men employed has diminished over the last five years.
A new and larger plant began production in 1952 and the men had to accustom themselves to a strange environment, with frequent modifications of the process at first, while maintaining a reasonable standard of production (Table 1). As the new plant was situated in a different part of the country from the old, several of the men who accepted a transfer from one to the other had to readjust themselves to new domestic as well as industrial environments while others were newly engaged with no previous experience of the chemical industry. These facts may account to some extent for the high incidence of dermatitis during the early days at the new plant, whereas, during the last three years there have been few cases of dermatitis (Evans, 1958).

TABLE 1

DERMATITIS IN FORMALDEHYDE PLANTS

\begin{tabular}{|c|c|c|c|c|c|}
\hline & Year & $\begin{array}{c}\text { Average No. } \\
\text { of Workers } \\
\text { (approx.) }\end{array}$ & $\begin{array}{c}\text { No. of } \\
\text { New Cases } \\
\text { of } \\
\text { Dermatitis }\end{array}$ & $\begin{array}{c}\text { Change of } \\
\text { Employment } \\
\text { on Account } \\
\text { of } \\
\text { Dermatitis }\end{array}$ & $\begin{array}{l}\text { Lost Time } \\
\text { Cases }\end{array}$ \\
\hline$\frac{5}{\frac{5}{2}}$ & $\begin{array}{l}1945 \\
1946 \\
1947 \\
1948 \\
1949 \\
1950\end{array}$ & $150-250$ & $\begin{array}{r}9 \\
10 \\
11 \\
9 \\
16 \\
15\end{array}$ & $\begin{array}{l}\text { High } \\
\text { labour } \\
\text { turnover }\end{array}$ & $\begin{array}{l}1 \\
6 \\
1 \\
4 \\
2 \\
2\end{array}$ \\
\hline $\begin{array}{l}\frac{z}{5} \\
\frac{z}{2} \\
z \\
z\end{array}$ & $\begin{array}{l}1952 \\
1953 \\
1954 \\
1955 \\
1956 \\
1957\end{array}$ & $\begin{array}{l}275 \\
270 \\
260 \\
230 \\
225 \\
220\end{array}$ & $\begin{array}{r}29 \\
45 \\
15 \\
4 \\
7 \\
2\end{array}$ & $\begin{array}{c}\mathrm{Nil} \\
14 \\
3 \\
\mathrm{Nil} \\
\mathrm{Nil} \\
\mathrm{Nil}\end{array}$ & $\begin{array}{l}1 \\
1 \\
3 \\
- \\
-\end{array}$ \\
\hline
\end{tabular}

Only five men lost time in the new plant and 17 were transferred to other employment on account of dermatitis, most of them in one year. Ninety-five per cent of the men who developed dermatitis in the new plant were successfully treated while continuing at work and lost no time. This compares with $77 \%$ who similarly lost no time in the old plant, an improvement which was probably associated with a number of factors. The new plant has improved and more conveniently situated washing facilities. There has probably also been a tendency over the years for men who are prone to develop dermatitis to seek other employment of their own accord.

Polyvinyl Chloride.-This material is made by polymerizing the narcotic gas vinyl chloride $\left(\mathrm{CH}_{2}: \mathrm{CHCl}\right)$. The pure polymer is inert and neither toxic effects nor dermatitis have been experienced by those who have handled it for several years. Plasticizers, stabilizers, lubricants, pigments, and other substances are frequently added to it, in order to modify its physical properties, and, since any of these may slowly leach or be extracted from the final article, it is essential to ensure that they are harmless, especially for certain uses. 
A typical example is the commonly used plasticizer tricresyl phosphate, the ortho-isomer of which is a notoriously dangerous poison. Its effects have been fully described (Hunter, 1955) and the most recently reported outbreak occurred in 1955 in Durban and involved 11 people (Susser and Stein, 1957). An interesting feature of the latter occurrence is the fact that it probably arose from drinking water stored in contaminated drums that had been taken from a local paint factory where "this compound was freely used without special precautions".

Derivatives of phthalic acid, which are often used as plasticizers for polyvinyl chloride, are almost all of a low order of toxicity. This has been shown by Mallette and Haam (1952b) and Smith (1953), and the negligible chronic toxicity of the widely used di-2-ethylhexyl phthalate has been demonstrated in animal feeding experiments by Harris, Hodge, Maynard, and Blanchet (1956). A worker who mistakenly swallowed a tablespoonful of the rather more toxic dibutyl phthalate cleveloped bilateral keratitis with albumin and blood cells in the urine within 48 hours (Cagianut, 1954). He recovered after 14 days in hospital and the case is of interest since the compound has been freely used on the human skin as an insect repellant (British Medical Journal, 1947).

Lead salts may be added to polyvinyl chloride as heat or light stabilizers and may constitute a hazard if they are used in powder form. A report by Goss and Ross (1953) suggested that the use of lead paste eliminated the danger of poisoning by inhalation, but in fact this only applies provided good general, and especially local, exhaust ventilation is installed and regularly inspected. In addition such an apparently fool-proof method of suppressing dust does not eliminate the necessity for routine estimations of lead in the atmosphere to ensure that the level is kept below $0.15 \mathrm{mg}$./cu. metre.

Cadmium compounds are sometimes used as stabilizers or pigments for polyvinyl chloride and a comprehensive literature exists on their toxicity (Fairhall, 1957a). Most of the reported cases of poisoning have been due to ingestion of the soluble salts of cadmium. Gabby (1950) has shown, however, that insoluble pigments such as calcined cadmium sulphide and selenide were harmless when relatively high concentrations were ingested by experimental animals. This is comparable with the extreme toxicity of soluble barium salts as opposed to insoluble barium sulphate, large quantities of which are daily consumed by patients as barium meals for radiological investigations (Smith and Cook, 1948).

To ensure that the plastic material in which these pigments are incorporated is free from toxicity it must also be shown for certain specialized applications that they cannot be extracted by such solvents as those mentioned below under "Food Applications". Workmen must not be exposed to the risk of inhaling dust or fume emanating from soluble or insoluble compounds.

Reference books almost without exception describe tin and its compounds as relatively harmless substances and Fairhall (1957b) states that it is one of the least toxic of the common metals when ingested as a salt. These statements are true with regard to tin itself and many of its inorganic salts which are insoluble in water, but certain organic tin compounds such as the alkyl derivatives are soluble and readily absorbed. In recent years the latter derivatives have been used more and more as heat stabilizers for polyvinyl chloride, especially in its unplasticized form. Stoner, Barnes, and Duff (1955) demonstrated that many alkyl tins are toxic to animals and stressed the need for care in handling these compounds during manufacture, as some of them can be absorbed through the skin. Barnes and Stoner (1958) confirmed these findings in a more detailed investigation of a larger number of alkyl tin compounds, but they drew attention to the fact that some of the higher homologues, such as the dioctyl and dinonyl derivatives, are relatively harmless, whether absorbed by mouth or applied to the skin in large doses. Both these papers refer to the disastrous occurrence in France when several deaths were reported as the result of the oral administration of diethyl tin diiodide to patients. Apart from the higher homologues already mentioned, therefore, all alkyl tin derivatives should be excluded from plastic materials likely to be used in contact with food, unless it is shown that they cannot be extracted from the plastic.

Polyolefines.-In addition to polythene, other plastics are now being manufactured from polymerized unsaturated hydrocarbons of the olefine series and some of these processes involve the use of catalysts that may be dangerous. Aluminium alkyl compounds of a low molecular weight, for example, are used for this purpose and they are spontaneously inflammable in air so that difficulty may be experienced in handling them. Knap, Leech, Reid, and Tamplin (1957) described the hazards of these compounds and drew attention to the possibility of pulmonary damage in experimental animals exposed to their fumes. For safety aluminium alkyl compounds are usually handled in solution but even so they can produce burns that are extremely painful and usually slow to heal.

A research worker suffered burns as a result of splashes from a small quantity of a $20 \%$ solution of an aluminium 
alkyl compound which blew out of a chemical flask. Although the patient's skin and eyes were immediately irrigated, he suffered painful burns of the neck, shoulder, both hands, and the left eye. Irrigation of the eye was prolonged and uninterrupted while he was conveyed to hospital by ambulance after the burns had been covered with dry sterile dressings. Two days later the skin had blistered but thereafter healing proceeded satisfactorily with treatment by exposure and the administration of systemic penicillin and early physiotherapy. The eye burn healed within a few days. The incident stresses the importance of immediate and prolonged irrigation in such cases.

Polytetrafluoroethylene.-Polymers made from fluorine compounds possess exceptional properties which make them most useful plastic materials, one of the most important of which is polytetrafluoroethylene ("fluon"). The monomer is of a low order of toxicity but its purification results in the production of highly toxic residues; the process is therefore totally enclosed and handling is by remote control for the protection of the worker. The final polymer is extremely inert and is unaffected by strong acids, alkalis, or solvents and is harmless to experimental animals when ingested.

A sample containing about $21 \%$ polytetrafluoroethylene was incorporated to the extent of $0.5 \%$ by weight in the diet of a group of rats of both sexes. The experiment lasted about seven months after which no ill-effects were observed and no difference was noted in the average body weights of the experimental and control groups of animals. Histological examination of the body organs revealed no abnormality.

The influenza-like attacks that result from inhaling the fume emanating from this polymer when it is heated to high temperatures have already been reported (Harris, 1951). Sherwood (1955) described the clinical details in seven workmen affected in this way and observed that all but one of the men smoked at work. One or two particles of the polymer burnt on a cigarette seem sufficient to cause the fever. Sherwood states that smoking contaminated tobacco is probably the most likely cause of this condition, certainly more probably than machining or turning the product on a lathe, which was formerly considered to be a possible source of the fume.

A typical case was that of the workman engaged on machining the polymer who complained to his foreman of headache and shivering attacks and thought he was suffering from influenza. The foreman for reasons best known to himself thought the man was possibly malingering but allowed him to stop work and go home. Since it was an urgent job the foreman decided to finish it and incidentally helped himself to tobacco and cigarette papers that had been left on the machine by the work- man. Later that evening in his home he developed a headache, tightness of the chest, and attacks of shivering, and he too thought that this was due to influenza. He went to bed and passed an uneventful night and the next morning both men returned to work having fully recovered. The symptoms, the obvious latent interval in the case of the foreman, and the rapid recovery are typical of the fever produced by polytetrafluoroethylene fumes.

Experimental work shows that fumes begin to be evolved when the polymer is heated above $250^{\circ} \mathrm{C}$.; at higher temperatures exposed animals died of pulmonary oedema.

Rats were exposed to the fumes emanating from samples of "fluon" heated to $250^{\circ} \mathrm{C}$., $275^{\circ} \mathrm{C}$., and $300^{\circ} \mathrm{C}$. for periods of six hours. At $250^{\circ} \mathrm{C}$. there were no ill-effects. At $275^{\circ} \mathrm{C}$. the rats showed signs of irritation but recovered after exposure. Postmortem examination showed no abnormality. At $300^{\circ} \mathrm{C}$. the vapours were lethal. Respiratory distress occurred after four hours' exposure and at necropsy the lungs were discoloured and oedematous but other organs appeared normal. A histopathological examination of the lungs showed severe congestion with some areas of haemorrhage and oedema but again no abnormality was found in other organs.

The offending decomposition product is unknown but Zapp, Limperos, and Brinker (1955) gave the results of a detailed investigation of the products evolved at different temperature ranges. Above $500^{\circ} \mathrm{C}$. the decomposition of the polymer proceeds rapidly enough to make it possible to identify the products in that particular range which consist of tetrafluoroethylene monomer, other fluorocarbon gases, a high boiling residue, and traces of hydrogen fluoride. The most toxic compound was found to be octafluoroisobutylene, which is lethal in a few hours to rats in concentrations as low as 0.5 p.p.m., but it cannot be regarded as the causative agent since the symptoms produced in animals are different from those in man.

Butadiene Copolymers. The combination of two monomers in the manufacture of a plastic material is not new and a typical example of such a copolymer is that made by polymerizing a mixture of vinyl acetate and vinyl chloride. One of the most important synthetic chemicals used today in the manufacture of plastics is butadiene which is produced at the rate of nearly a million tons annually. Although capable of polymerization on its own, it is mainly combined for this purpose in industry today in varying proportions with monomers such as styrene, acrylonitrile, or methyl methacrylate to give a wide range of products. Depending on the relative proportions of the monomers the final materials vary in 
composition from hard resins to soft rubbers, some of which have become widely known as synthetic rubbers. Suspensions of these copolymers are also used in emulsion paints, for coating printing paper, and as bases for leather finishes and non-woven fabrics. Each monomer will now be considered separately.

Butadiene (Vinyl Ethylene $\mathrm{CH}_{2}: \mathrm{CHCH}: \mathrm{CH}_{2}$ ).This is a gas with a very low order of toxicity, acting as a mild narcotic only in such high concentrations (Carpenter, Shaffer, Weil, and Smyth, 1944) that the safe level for factory atmospheres has been set at 2,500 p.p.m. Wilson, Hough, and McCormick (1948) state that there is $n \supset$ apparent systemic injury to human beings in concentrations below 5,000 p.p.m. In one investigation by Wilson (1944) a group of workmen exposed to butadiene vapour and complaining of symptoms were immediately examined (including chest radiographs and blood examinations) with negative results, as also were the follow-up examinations.

Styrene (Vinyl Benzene $\mathrm{C}_{6} \mathrm{H}_{5} \mathrm{CH}: \mathrm{CH}_{2}$ ). - This is an oily liquid which is a moderate skin and mucous membrane irritant possessing anaesthetic properties in high concentrations (Clinton, 1948). It has a characteristic disagreeable odour, and Spencer, Irish, Adams, and Rowe (1942) suggest that the extreme nose and eye irritation produced in man by a concentration of 1,300 p.p.m. affords a definite safeguard against voluntary exposure to acutely hazardous concentrations. Men exposed to styrene fumes and complaining of toxic effects were sent to hospital for examination (including complete blood count and chest radiograph) and no pathological condition was found even in men who were observed for at least one year subsequently (Wilson, 1944). The maximum permissible concentration in the atmosphere in any factory should not exceed 100 p.p.m.

No case of poisoning or dermatitis due to styrene has occurred in the plants considered here but one incident is quoted to stress the importance of anticipating every contingency and of avoiding paying undue attention to the effects of only the main chemicals being handled.

Three men working in the packing section beneath a drier became ill with nausea and vomiting and were taken to the medical department where they quickly recovered after treatment. It was assumed that they had been exposed to excessive amounts of styrene vapour, apparently the only substance present which might have caused the illness. The plant was temporarily closed to improve the ventilation and two days later two other men engaged on this task were overcome with nausea, giddiness, and headache. They were escorted to the ambulance room where they recovered after rest and oxygen therapy.
No clinical abnormality was found and they were sent home.

An immediate inspection of the packing cubicle after the second incident revealed a smell of coal gas which was in fact oxidized in order to supply the drier with atmospheric nitrogen so as to eliminate an explosive hazard in the process. Analyses showed $0.15 \%$ carbon monoxide in the atmosphere at working level, which had accumulated as the result of a leak from a faulty valve. This is a dangerous concentration of carbon monoxide which can lead to unconsciousness and possibly death in about two hours (Johnstone, 1941).

Schwartz (1945) is of the opinion that most of the occupational dermatitis occurring in the manufacture of certain butadiene-styrene copolymers is caused by chemicals added to make the reaction possible and is not due to either monomer.

Acrylonitrile (Vinyl Cyanide $\mathrm{CH}_{2}: \mathrm{CHCN}$ ). - This is a colourless liquid which acts as a systemic poison resembling cyanide when absorbed by ingestion, inhalation, or through the intact skin. There is little or no evidence that it has a cumulative effect (Dudley, Sweeney, and Miller, 1942). A summary of its properties, uses, and methods of safe handling is given by the Manufacturing Chemists Association (1949). Brieger, Rieders, and Hodes (1952) demonstrated high cyanide levels and the presence of cyanmethaemoglobin in animals exposed to the vapour, proving that the toxicity of acrylonitrile is based on the formation of cyanide in the body. This had been suggested by Dudley and Neal (1942) who found that the injection of sodium nitrite had a protective and antidotal action on animals. Although a few cases with symptoms-such as nose, throat, eye, and skin irritation, headache, jaundice, and a low-grade anaemia-have been reported (Wilson et al., 1948), no fatality or even serious poisoning has occurred in industry where thousands of tons of acrylonitrile have been manufactured and handled. Dudley and Neal (1942) described one case in a laboratory worker who spilled small quantities of the liquid on his hands and later developed blisters, peeling, and cracking of the skin.

Rubber gloves are not a satisfactory protection as the liquid dissolves rubber, but they may be used for short spells when handling the latices or partially polymerized materials. Contamination of the skin demands immediate and prolonged irrigation, and treatment of systemic poisoning is identical with that of cyanide poisoning (Potter, 1950). Eye irrigation bottles and cyanide first aid equipment must be readily and conveniently available in selected places on the plant, and a special cyanide emergency kit such as that described by Lloyd (1957) should be kept in the medical department on sites where acrylonitrile is made or handled. Atmospheric concentrations should not exceed 20 p.p.m. No incidents have 
occurred in the plants under review but considerable precautions are taken in the form of enclosed processes, good ventilation, and education of the worker.

Methyl Methacrylate $\left(\mathrm{CH}_{2}: \mathrm{C}\left(\mathrm{CH}_{3}\right) \mathrm{COOCH}_{3}\right)$.This monomer has already been described as an extremely mild irritant and toxic by inhalation (Deichmann, 1941) but only in such high concentrations as over 1,000 p.p.m.

The hazards of all monomers mentioned in this section are confined to the manufacturing process and may only be experienced in the factory as the result of accidents or unsatisfactory environmental conditions. Apart from rare cases of sensitization the polymers are inert and harmless.

The Uses of Plastics in Containers for Food

There is a rapidly growing demand for plastic articles for use in contact with food and beverages, which is not surprising in view of their lightness, inertness, clean appearance, and durability. The list of such applications is already extensive but below are a few typical examples together with some of the polymers from which they are made:-

\begin{tabular}{|c|c|}
\hline Application & Polymer \\
\hline $\begin{array}{l}\text { Tubes for conveying liquids } \\
\text { Wrapping films }\end{array}$ & $\begin{array}{l}\text { Polythene, polyvinyl chloride } \\
\text { Polythene, polystyrene, poly- } \\
\text { ethylene terephthalate }\end{array}$ \\
\hline Coated paper cartons & Polythene, formaldehyde pro- \\
\hline Beakers, cups, bowls, bins & $\begin{array}{l}\text { Polymethyl methacrylate, poly- } \\
\text { styrene, polythene, urea } \\
\text { formaldehyde }\end{array}$ \\
\hline $\begin{array}{l}\text { Bakers' roller mills (linings) } \\
\text { Food conveyor belts } \\
\text { Gears, bushes, and mixing } \\
\text { machinery }\end{array}$ & $\begin{array}{l}\text { Polytetrafluoroethylene } \\
\text { Nylon, polyvinyl chloride } \\
\text { Nylon }\end{array}$ \\
\hline $\begin{array}{l}\text { Refrigerator trays and linings } \\
\text { Soft drink containers and dis- } \\
\text { pensers }\end{array}$ & $\begin{array}{l}\text { Polyvinyl chloride, polystyrene } \\
\text { Polymethyl methacrylate, } \\
\text { polystyrene }\end{array}$ \\
\hline
\end{tabular}

The manufacturers of plastic articles should ensure that food or drink is not affected by them, as this might constitute an offence against Sections 1 and 2 of the Food and Drugs Act, 1955. It is fortunate that the inert property that renders plastic materials useful in this and other fields also generally implies that the product is harmless. It has already been mentioned, however, that plastic materials may contain other chemicals besides the polymer and in certain circumstances these additives may be extracted by the food or beverage in contact with the plastic product. Lead salts, for example, are readily extracted from plasticized polyvinyl chloride so that they rapidly contaminate liquids conveyed in tubes made from this product.

Attention has already been drawn to the fact that the solubility of a substance influences its degree of toxicity, e.g., lead, cadmium, barium, and tin compounds, so that the initial and sometimes only investigation required to ensure that plastic materials are harmless is to determine whether the products or their ingredients are soluble in, or can be extracted by, the food with which they will be in contact. Lehman (1951) states with regard to food packaging materials that if the film or any of its components may be shown to be insoluble, there is no problem of toxicity. He emphasizes, however (Lehman, 1956), that the tests demand extremely sensitive analytical methods if they are to be of any value.

The obvious substance to use for extraction tests is the food itself but the practical difficulties of microanalysis make it simpler in practice to use a range of solvents of known strength. For this purpose the following minimum list, to which others may be added if experience makes it necessary, has recently been suggested by the British Plastics Federation (1958):-(a) Distilled water, (b) a $5 \%$ $\mathrm{w} / \mathrm{v}$ aqueous solution sodium carbonate (anhydrous), (c) a $6 \% \mathrm{w} / \mathrm{v}$ aqueous solution hydrochloric acid, (d) a $50 \% \mathrm{w} / \mathrm{v}$ aqueous solution of ethyl alcohol, and (e) olive oil (B.P.C.) to which $2 \% \mathrm{w} / \mathrm{w}$ of oleic acid has been added. Extraction should be carried out at about $60^{\circ} \mathrm{C}$. for as long as a week or even a month. The conditions of extraction are described in detail by the British Plastics Federation (1958); they do not differ to any great extent from those recommended by Lehman (1956). In all cases of doubt or lack of knowledge, the degree of toxicity of the chemical substances present must be assessed by pharmacological methods which may involve prolonged investigations. The information that such toxicity tests should provide and some of the considerations which govern the conditions of use of toxic materials in general have been described by the Medical Research Council (1957). One or two practical problems may be of interest.

(a) Polythene tubing has proved valuable for conveying cold water under difficult conditions of terrain over long distances, such as those experienced in providing water for agricultural needs. The inert tubing normally does not in any way affect the water. Polythene is known, however, to be pervious to gases and one or two instances have occurred where the water has been contaminated by leaking gas or sewer mains lying near the plastic tube.

(b) Polytetrafluoroethylene has proved a useful material for lining bread and cake tins and coating dough rollers as it prevents the food adhering to the equipment. Extraction tests on this product gave negligible results and, as shown above, prolonged feeding tests had no effect on the health of experimental animals. Coppock and Knight (1957) found that traces of fluorine were absorbed from these linings when they were first heated. The amount absorbed, however, could be reduced to consider- 
ably less than the proposed limit for the fluorine content of self-raising flour (Ministry of Agriculture, Fisheries and Food, 1957) if the lined containers were subjected to suitable initial heating before use.

(c) Bottles manufactured from one particular nylon copolymer were said to impart an unpleasant flavour to liquids contained in them. This was found to be due to the extraction from the product of small quantities $(0.2 \%$ on prolonged boiling) of low molecular weight constituents. Acute and chronic toxicity tests of this extract showed that (1) no illeffects were observed in a group of rats receiving six oral doses of 0.5 to $2 \mathrm{~g} . / \mathrm{kg}$. of the extract in arachis oil solution for eight days compared with control animals which received the oil only. No abnormality was found post mortem. (2) The extract was given to a group of young rats in their drinking water in a concentration of 400 p.p.m. This dose was continued for nearly six months during which time no ill-effects were observed and the average weights at the end of the period compared favourably with those of the control animals. Post-mortem and histological examination of the body organs showed no abnormality.

These findings, however, do not justify the use of the nylon copolymer for this application since the liquid was contaminated albeit by a harmless substance.

\section{The Use of Plastics in Surgery}

Probably the most decisive evidence of the safety of the use of selected plastics in contact with food and consumable liquids is provided by the large number of successful implantations in human tissues for surgical purposes.

An increasing number of surgical uses is being found for plastics but only a brief reference to the subject can be made here. The results in general are very encouraging but it must be admitted that unsuitable materials are sometimes selected by surgeons because they fail to seek technical advice about the properties of the products. The result can bring into disrepute plastic materials which might otherwise be of inestimable benefit to many patients.

A variety of surgical applications of plastics was described by Ingraham, Alexander, and Matson (1947) and by Bing (1950), and a brief summary was given in a leading article in the British Medical Journal (1952) but there is some divergence of opinion in these and other accounts about the reaction of the tissues to plastic implantations. Most reports and the now extensive experience with these materials confirm the inert nature of many of them, especially when they contain no additives or these cannot be extracted by tissue fluids. There is a tissue response, however, as shown by LeVeen and Barberio (1949), who investigated the effects of implanting four different plastics in dogs and found that "teflon" (polytetrafluoroethylene) was the only polymer that did not produce a proliferative foreign body reaction. Scales (1953b) described tissue reactions to a few synthetic materials but it appears that such reactions are usually due to misuse of the plastic, such as subjecting it to highly mobile or weight-bearing conditions (Newman and Scales, 1951). Nylon cups fitted on the femoral head become abraded when they are subjected to weightbearing so that fine particles of the polymer cause a proliferative tissue reaction with areas of necrosis; six instances of this unsuitable use of the material have been described by Scales (1957).

Most of the unsatisfactory applications have occurred in orthopaedic surgery, where plastics have been very extensively used. One of the most popular but least satisfactory applications has been the acrylic hip prosthesis (Judet and Judet, 1950) of which a large number have proved failures (Pridie, 1953), and the biomechanical and other problems involved in this arthroplasty described by Scales and Zarek (1954) and by Buxton (1955) should be carefully studied if this operation is contemplated. A detailed account was given by Scales (1958b) of the problems involved in the use of plastics and metals in prosthetic surgery.

In contradistinction to these findings Seddon and Scales (1949) inserted a polythene substitute for the upper part of a diseased femur which to date has been successful (Scales, 1958a). A man suffering from polyostotic fibrous dysplasia with a long history of pathological fractures of the femur had the bone replaced by an acrylic prosthesis (Figs. 1 and 2) which still proved satisfactory after seven years (Burrows, 1958). Another patient had undergone many operations over a period of 26 years for osteomyelitis of the femur but still suffered pain that treatment, including lumbar sympathectomy, had failed to relieve, and Bingold (1954) replaced the diseased stump with an acrylic prosthesis which has resulted in "a completely painless stump with a full range of movements" (Bingold, 1958). Although these patients have artificial limbs it should be emphasized that in each case the prosthesis bears no weight.

The importance of selecting precisely the right material in its most suitable form is emphasized by Moloney (1958) who investigated the results of nylon repairs of herniae in over 2,000 cases. He found that monofilament suture material was the most satisfactory and produced better results than the braided type in these operations. 


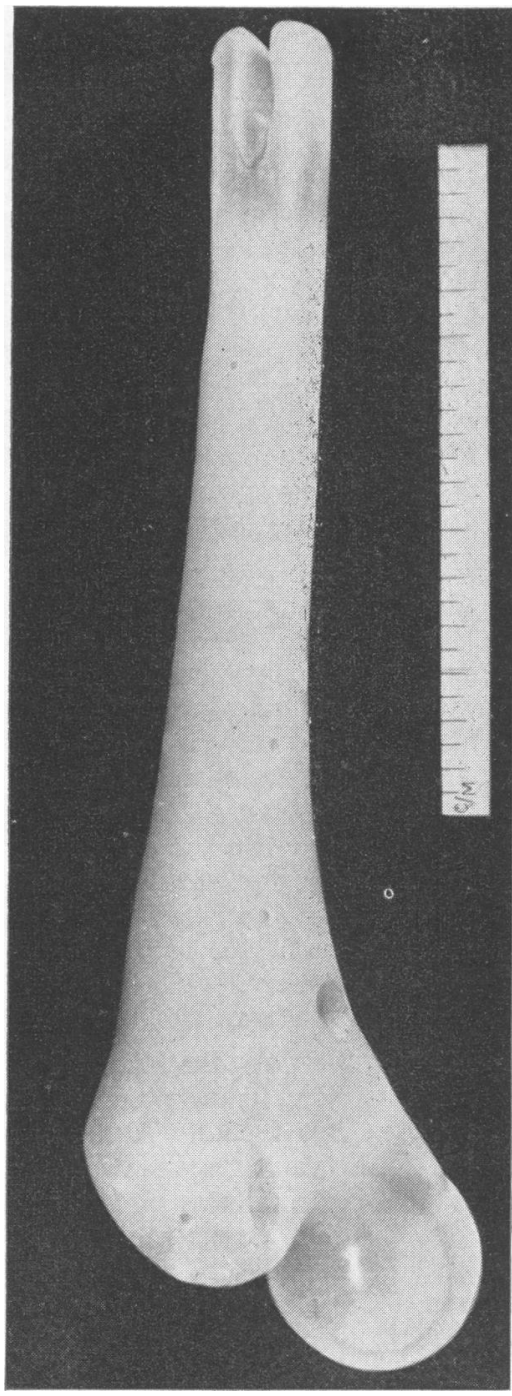

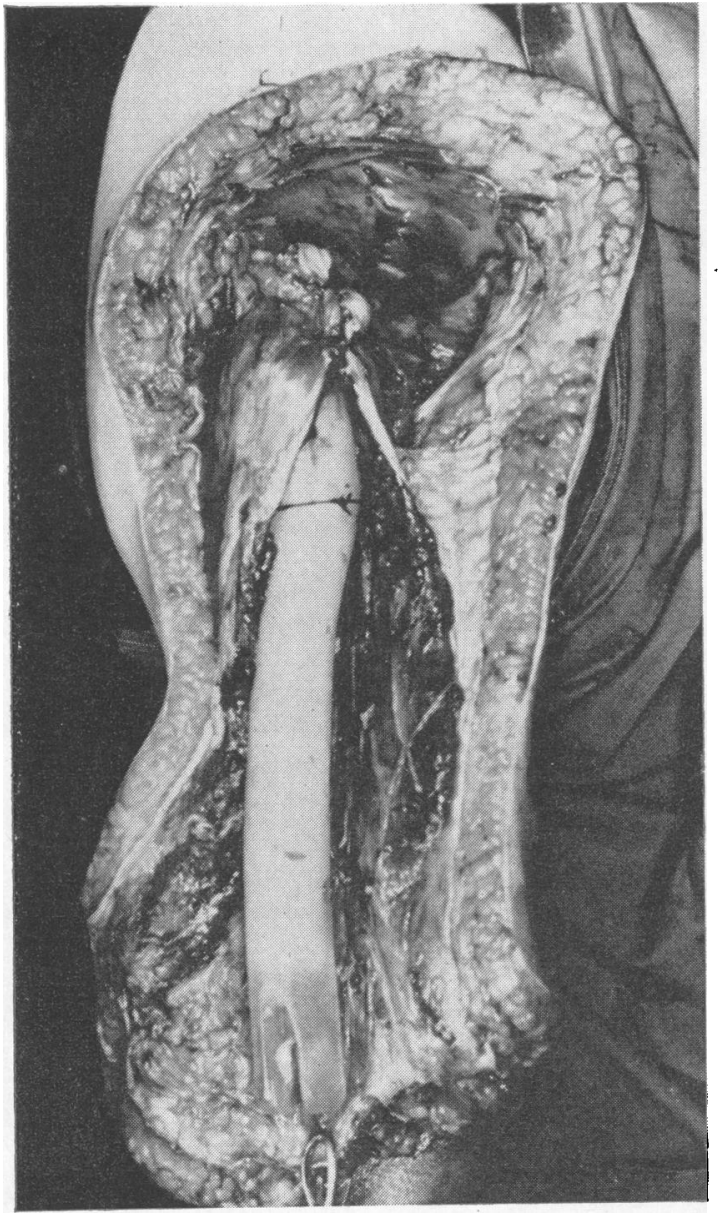

FIG. 2.

FIG. 1.-Acrylic prosthesis for the upper part of the femur.

FIG. 2.-Acrylic prosthesis inserted in the thigh.

By courtesy of the Institute of Orthopaedics.

Eastcott and Wilson (1958) record the use of "orlon" (polyacrylonitrile) cloth for an aortic graft which for over two years proved almost inert to the host cells and tissues and produced negligible reaction although functioning efficiently during this time.

Valvular prostheses have been used in cases of aortic insufficiency by Hufnagel, Harvey, Rabil, and McDermott (1954) who described the results as extremely encouraging. Hufnagel (1955) states that an acrylic valve fixed by nylon rings has been inserted in the aorta in about a hundred cases and concludes that the procedure has been of value for patients with this disability.

Another interesting application has been the intraocular implantation of an acrylic substitute for the lens of the eye in cases of cataract. Ridley (1956) asserts that no more effective treatment for monocular cataract has yet been devised. He has now performed about 600 acrylic lens operations and states that the material can be tolerated in the human eye for eight years and, as far as we can tell, indefinitely (Ridley, 1958).

These few examples indicate that plastic implantations in tissue may remain for many years without toxic or initiative effects. An extensive bibliography on the subject has been compiled by Grau (1956).

\section{Conclusion}

It is seldom that a group of materials has invaded the everyday lives of people as rapidly as plastics and 
yet the industry is still in its infancy. With the exception of food and drugs few substances can have been subjected to such thorough investigations to ensure freedom from harm to those who make and use them. This continues to be essential and all manufacturers of the raw chemical materials should be provided with extensive laboratory facilities and a modern technical service to deal with the problems that arise in the fabrication and use of plastics.

In a well-balanced reference to the subject Dodds (1953) states that the moral is to perfect the system of investigation and control which would seem to be a more practicable solution than to suppress or ban the use of chemicals.

In the surgical field it is suggested that a more cautious approach is indicated by the failures due either to misapplication or sometimes to the use of the wrong plastic materials. It might seem unnecessary to suggest that each patient ought to be considered as an individual case but the production of thousands of Judet acrylic prostheses in a few different sizes without adequate laboratory investigation (Scales, 1953a) indicates that patients are often in fact not treated in this way. The wide use of plastics in orthopaedic surgery demands a very close liaison between the surgeon and the designer of the plastic prosthesis before, during, and after the operation. Ideally it also requires the provision of a special workshop as a separate department in any large orthopaedic hospital where the plastic appliance can be adequately prepared and tested. When suitably designed for selected cases plastic prostheses have proved invaluable.

I am grateful to Mr. H. Ridley, Mr. Jackson Burrows, Mr. A. C. Bingold, and Dr. John T. Scales for comments on their use of plastics in surgery; to the I.C.I. Industrial Hygiene Laboratories for their toxicological reports, and to many colleagues in Imperial Chemical Industries Limited for their generous advice and help.

\section{REFERENCES}

Barnes, J. M., and Stoner, H. B. (1958). Brit. J. industr. Med., 15, 15

Bing, J. (1950). Acta chir. scand., 100, 293.

Bingold. A. C. (1954). Proc. roy. Soc. Med., 47, 11.

Bingold, A. C. (1954). Proc. roy. Soc.

Brieger, H., Rieders, F., and Hodes, W. A. (1952). A.M.A. Arch. industr. Hyg., 6, 128 .

British Medical Journal (1947), 1, 552. [“Any Questions."]

B- (1952), 1, 750.

British Plastics Federation (1958). Report of the Toxicity SubCommittee. London.

Burrows, H. Jackson (1958). Personal communication.

Buxton, St. J. D. (1955). Arthroplasty. Pitman, London.

Cagianut, B. (1954), Schweiz. med. Wschr., 84, 1243.

Carpenter, C. P., Shaffer, C. B., Weil, C. S., and Smyth, H. F. (1944). J. industr. Hyg., 26, 69.
Clinton, M. (1948). Toxicological Review. American Petroleum Institute, New York

Coppock, J. B. M., and Knight, R. A. (1957). Brit. med. J., 2, 355. [Correspondence.]

Deichmann, W. (1941). J. industr. Hyg., 23, 343.

Dodds, E. C. (1953). Lancet, 1, 1211.

Dudley, H. C., and Neal, P. A. (1942). J. industr. Hyg, 24, 27.

, Sweeney, T. R., and Miller, J. W. (1942). Ibid., 24, 255

Eastcott, H. H. G., and Wilson, R. R. (1958). Lancet, 1, 352

Evans, S. Jenkin (1958). Personal communication.

Fairhall, L. T. (1957a). Industrial Toxicology, 2nd ed., p. 30. Williams and Wilkins, Baltimore.

(1957b). Ibid., p. 125.

Gabby, J. L. (1950). Arch. industr. Hyg., 1, 677.

Goss, A. E., and Ross, A. M. (1953). Amer. industr. Hyg. Ass. Quart., 14,41 .

Grau, H. R. (1956). Transplant. Bull., 3, 109.

Grau, H. R. (1956). Transplant. Bull.,

Harris, D. K. (1951). Lancet, 2, 1008. 255

Harris, R. S., Hodge, H. C., Maynard, E. A., and Blanchet, H. J. (1956). A.M.A. Arch. industr. Hlth, 13,259.

Hine, C. H., Kodama, J. K., Anderson, H. H., Simonson, D. W., and Wellington, J. S. (1958). Ibid., 17, 129.

Hufnagel, C. A. (1955). Cardiovascular Surgery, p. 321. W. B. Saunders, Philadelphia.

Harvey, W. P., Rabil, P. J., and McDermott, T. F. (1954) Surgery, 35, 673.

Hunter, D. (1955). The Diseases of Occupations. English Universities Press, London.

Ingraham, F. D., Alexander, E., and Matson, D. D. (1947). New Engl. J. Med., 236, 362 and 402.

Johnstone, R. T. (1941). Occupational Diseases, p. 175. W. B. Saunders, Philadelphia.

Judet, J., and Judet, R. (1950). J. Bone Jt Surg., 32B, 166

Knap, J. E., Leech, R. E., Reid, A. J., and Tamplin, W. S. (1957). Industr. Engng Chem., 49, 874.

Lehman, A. J. (1951). Quart. Bull. Ass. Food and Drug Officials of the United States, XV, 82.

(1956). Ibid., XX, 159.

LeVeen, H. H., and Barberio, J. R. (1949). Ann. Surg. 129, 74.

Lloyd, N. Langdon (1957). Brit. J. industr. Med., 14, 137.

Mallette, F. S., and Haam, E. von (1952a). A.M.A. Arch. industr. Hyg. 5 , 311.

Manufacturing Chemists Association Inc. (1949). Chemical Safety Data Sheet S.D.-31. Washington, D.C.

Medical Research Council (1957). Monthly Bull., Minist. Hith. Lab. Serv. 16, 2.

Ministry of Agriculture; Fisheries and Food (1957). Food Standards Committee Report on Fluorine. H.M.S.O., London.

Moloney, G. E. (1958). Lancet, 1, 273.

Newman, P. H. and Scales, J. T. (1951). J. Bone Jt Surg., 33B, 392.

Oettel, H. (1957). Naunyn-Schmiedeberg's Arch. exp. Path. Pharmak., 232, 77.

Parmeggiani, L., and Sassi, C. (1955). Med. d. Lavoro, 46, 14.

Potter, A. Lloyd (1950). Brit. J. industr. Med.. 7, 125.

Pridie, K. H. (1953). Brit. med. J., 2, 939. [Correspondence.]

Ridley, H. (1956). J. int. Coll. Surg., 26, 335.

- (1958). Personal communication.

Scales, J. T. (1953a). J. Bone Jt Surg., 35B, 6.

- (1953b). Proc. roy. Soc. Med. 46, 647 .

(1957). Acta orthop. scand., 27, 13.

(1957). Acta orthop. scand., 27, 13.

(1958b). In Modern Trends in Surgical Materials, ed. L. Gillis p. 70. Butterworth, London.

- , and Zarek, J. M. (1954). Brit. med. J., 1, 1007

Schwartz, L. (1945). J. Amer. med. Ass., 127, 389.

-, Tulipan, L., and Peck, S. M. (1947). Occupational Diseases of the Skin, 2nd ed. Kimpton, London.

Seddon, H. J., and Scales, J. T. (1949). Lancet, 2, 795.

Sherwood, R. J. (1955). Trans. Ass. industr. med. Offr., 5, 10.

Smith, C. C. (1953). A.M.A. Arch. industr. Hyg., 7, 310.

Smith, S., and Cook, W. G. H. (1948). Taylor's Principles and Practice of Medical Jurisprudence, ed. S. Smith, 10th ed. Practice of Medical Jurisprudence, ed. S.

Spencer H. C. Irish, D. D Adams, E M., and Rowe, V. K. (1942). J. industr. Hyg., 24, 295 .

Stoner, H. B., Barnes, J. M., and Duff, J. I. (1955). Brit., J. Pharmacol., 10, 16 .

Susser, M., and Stein, Z. (1957). Brit. J. industr. Med., 14, 111.

Wilson, R. H. (1944), J. Amer. med. Ass., 124, 701

- , and McCormick, W. E. (1955). Industr. Med. Surg., 24, 491. Hough, G. V., and McCormick, W. E. (1948). Ibid., 17, 199

Zapp, J. A., Limperos, G., and Brinker, K. C. (1955). Paper to American Industrial Hygiene Association. 